\title{
A vidékfejlesztés helye a regionális tudományban
}

\section{The position of rural development in the regional science KÁPOSZTA JÓZSEF}

\begin{abstract}
KÁPOSZTA József: egyetemi professzor, Szent István Egyetem, Gazdaság- és Társadalomtudományi Kar; 2100 Gödöllő, Páter Károly u. 1.; kaposzta.jozsef@gtk.szie.hu; https:// orcid.org/0000-0002-1239-8541
\end{abstract}

KULCSSZAVAK: vidék; regionális tudomány; globalizáció; helyi erőforrásokra épülő fejlesztés

József KÁPOSZTA: full professor, Faculty of Economics and Social Sciences, Szent István University; Páter Károly u.1., H-2100 Gödöllő, Hungary; kaposzta.jozsef@gtk.szie.hu; https://orcid.org/0000-0002-1239-8541

KEYWORDS: rural areas; regional science; globalisation; place-based development

A rendszerváltás óta jelentősen megváltoztak a gazdaság és a társadalom alapvető struktúrái, folyamatai. A változások által érintett vidéki térségek és települések, az ott élő lakosok is új helyzetbe kerültek, és az ehhez való alkalmazkodás kényszere vagy kihívása további speciális problémákat, feszültségeket, egyben persze új lehetőségeket is teremtett. Az alapvető változások egyik leglényegesebb eleme a vidék fogalmának átalakulása, a vidék új szerepeinek megjelenése. Napjainkra a vidék már nem egyszerűen az élelmiszeralapanyag-ellátás színhelye, hanem újabb feladatok, funkciók ellátásáért felelős területté vált. Ezzel egy időben a hazai regionális tudomány a térbeli folyamatok elemzése révén önálló társadalomtudományi diszciplínává vált. Szerves fejlődése során több tértudományi területet is magához vonzott, a centrum- és perifériakutatások, a határmentiség problémakörének vizsgálata, a területi társadalmi elemzések mellett a város- és a vidékgazdasági kutatások is a regionális tudomány részeivé váltak. Ennek következtében az elmúlt évtizedek alatt a vidék- és területfejlesztés, a vidékgazdaság és a vidékpolitika oktatása, kutatása is a térbeliséggel foglalkozó tudományterületek meghatározó elemévé vált. Enyedi György szerint a vidékfejlesztés legfóbb célja a (primer, szekunder, tercier) gazdasági ágazatok közötti szoros vállalkozói integráció elősegítése, és az adott vidéki térben megvalósítandó fejlesztések egymásra épülése mellett a civil és önkormányzati szektor együttműködésére épülő és a jövőjüket formálni tudó, tevékeny, életképes vidéki társadalom kialakítása (Enyedi 1975).

A hazai tértudományi szakirodalom meghatározó definíciói szerint ma már a mezőgazdasági termelés fejlesztése mellett a vidékfejlesztés részének tekintjük

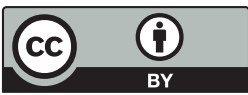


mindazon gazdasági, szociális, kulturális és ökológiai tényezők fejlesztését is, amelyek adott földrajzi terület gazdasági és társadalmi viszonyainak javítása mellett, az ott élők életminőségének javításán keresztül az egész nemzetgazdaság fejlődését szolgálják úgy, hogy egyidejüleg fenntartható módon megőrzik a táj természeti erőforrásait, a helyi kulturális örökséget (Buday-Sántha 2001). Mindezen összefüggések is jól mutatják, hogy a vidékfejlesztés mára már olyan össztársadalmi fejlesztések összefoglaló definíciójává vált, ami a vidéken élők jóllétének biztosítását, annak fejlődését tüzte zászlójára.

Napjainkban a globalizáció meghatározó szerepet játszik a vidékfejlesztés stratégiáinak változásában és a vidéki térségek átalakulásában, egyszerre jelentve lehetőségeket és fenyegetést. Egyrészt új lehetőségeket kínál a helyi vállalkozóknak új piacok megteremtésével, lehetővé teszi egyedi helyi termékek és szolgáltatások piacra jutását, áthidalva az izoláció vagy a távolságok korlátait (pl. interneten keresztüli forgalmazás). Sok esetben a korábbi tömegtermelésből kimaradt rurális területek - amennyiben fejlett infrastruktúrával és iskolázott lakossággal rendelkeznek - könnyebben fogadják be az új gazdasági szerkezeteket, mint a nehezen átképezhető munkaerővel rendelkező hagyományos iparvidékek (Ritter 2008). Másrészt a globalizáció a versenyhelyzetet is növeli, mivel a nemzetközi konkurencia betör a lokális piacokra. Ezzel meggyengülnek vagy eltűnnek a földrajzi, törvényi, identitásalapú közösségi határok, melyek eddig védték a vidéki területek termékeit, helyi iparát és kulturális tradícióit. Ennek kapcsán lényeges kiemelni, hogy a szakirodalomban a globalizáció - legtöbb esetben negatívan értelmezett - társadalmi hatásai különösen a vidéki területeket érintik. Fontos látnunk azonban a globalizációhoz kapcsolódó lokalizációt, amely a helyi értékek és a belső erőforrások szerepét helyezi előtérbe, és így a vidéki területek felértékelődéséhez, a lehetőségek kiszélesedéséhez vezet (Káposzta, Tóth 2013).

Az már az átalakuló nemzeti vagy nemzetközi gazdasághoz - kisebb vagy nagyobb mértékben, de többnyire - kötődő térségek tőkevonzó képességén múlik, hogy globalizáció vagy a lokalizáció hatása válik-e erősebbé. A vidéki funkciók változásának kutatói között egyetértés mutatkozik abban, hogy a vidéki térségeket az új funkciók és gazdasági szereplők megjelenése ellenére az urbanizált területekhez képest általános lemaradás, leszakadás jellemzi. A változásokban fontos szerepet játszott a mezőgazdaság mint a vidéki gazdaság korábbi (elsősorban foglalkoztatási szempontból jelentős) gerincének visszaszorulása, valamint az, hogy a globalizálódás következményeként a helyi erőforrásokra építon, lokális fejlesztések kerültek előtérbe. Az endogenitás ugyanis (miközben a vidéki térségek gazdasági és társadalmi fejlesztése nem tekinthet el a globalizáció kihívásaitól, amennyiben az adott térség versenyképességét akarja javítani), a helyi adottságokra alapozott társadalmi és gazdasági válaszok megfogalmazását segíti. A világgazdaság globális folyamatainak hatására - elsősorban a fejlettebb piacgazdasággal rendelkező országokban - világosan körvonalazódnak a vidék szerepének és funkcióinak változásai. Ezen változások (pl. a vidék elnéptelenedése, illetve egyes területek újranépesedése, az ingázás és a 
társadalmi mozgások, a növekvő rekreációs és tájfenntartási, környezetvédelmi igény, a gazdaság újszerü térbeli szerveződése) Európa nyugati országaiban már az 1970-es években jelentkeztek és felhívták a figyelmet egy következetes vidékfejlesztés szükségességére. Mindezen tényezők hatására a térhasználat új módjai fedezhetők fel, erősödik a szolgáltatások, az ipar és a technológia terjedése és mindeközben a vidéki területek egyre inkább differenciálódnak. Az európai vidéki térben új szereplők jelennek meg, akik különféle társadalmi alrendszerekből és gazdasági területekről érkeznek, és vidéki jelenlétük, müködésük is jelentősen különbözik. Ennek következtében mintegy újratermelődik az a társadalmi heterogenitás, ami a vidéki tereket a mezőgazdasági modernizáció előtt jellemezte.

Európa fejlettebb országaiban a fentebb vázolt átalakulás már többé-kevésbé lezajlott, Közép-Kelet-Európa országaiban, így hazánkban még nem zárult le, noha a folyamat itt sem napjainkban kezdődött. A hagyományos vidéki gazdaság és társadalom felbomlásának mértékét és intenzitását a falu, a mezőgazdaság és a parasztság kategóriáinak egymástól való eltávolodásával jellemezhetjük. A nem agrárfoglalkozásúak arányának növekedésével megindult a zárt, hagyományos agrártársadalom bomlása: a korábban a tulajdonviszonyok által ugyan tagolt, de egymást kiegészítő elemekből álló, egységes rendszert alkotó falusi közösségek differenciálódtak, illetve a településeken belül egymástól egyre inkább elkülönülő foglalkozási, társadalmi csoportok alakultak ki (Ritter 2008; Káposzta, Nagy 2013).

A változásokkal párhuzamosan a fejlett országokban újraértelmezik a vidékpolitikát. A vidéki területek fejlesztését célzó megközelítésekben a szektorális politikát a területi elvü és a vidéki térségek egészét érintő politikák váltják föl, miközben a vidékfejlesztés gazdasági dimenziói bővülnek. Életképes gazdasági bázis nélkül nem beszélhetünk életképes vidékről, enélkül a vidék funkciói (tájfenntartás, környezetvédelem, vidéki örökség megőrzése stb.) is jelentősen sérülnek.

A röviden bemutatott strukturális változások előtérbe helyezték a korunk vidékgazdaságához kapcsolódó felsőoktatás ki- és átalakítását, hiszen az innovatív, globalizált és automatizált gazdasági folyamatokat kell a hagyomány és a környezeti fenntarthatóság rendszerébe helyezni (Káposzta, Nagy 2013; Káposzta, Tóth 2013). A hazai agrárfelsőoktatás szakértői - a gazdasági agrármérnök ötéves osztatlan képzésének tapasztalataira alapozva - 2005-ben megalapították a gazdasági és vidékfejlesztési agrármérnök alapképzési és a rá épülő vidékfejlesztési agrármérnök mesterképzési szakot. Az újonnan megalapított szakok elsődleges szempontként kezelték az Enyedi György és Buday-Sántha Attila által körvonalazott vidékgazdasági összefüggésrendszert, és helyezték el a képzést a térgazdaságtanhoz kapcsolódó tudományos térben. Országosan ezen agrárképzési szakok voltak azok, melyek a vidékfejlesztés oldaláról közelítve, a képzések rendszerébe helyezték a regionális gazdaságtanhoz, a területi tervezéshez és az integrált területfejlesztéshez kapcsolódó diszciplínák oktatását, kutatását.

A vidékfejlesztési alap- és mesterképzési szakok első átfogóbb átalakítása 2016-ban történt meg, amikor - a képzés tízéves tapasztalatait is figyelembe 
véve - a kimeneti követelmények módosítása mellett az alapképzési szak elnevezése is módosult (vidékfejlesztési agrármérnök lett). A képzések tanterveiben az átalakítások után továbbra is meghatározó részt képviselnek a tértudományhoz kapcsolódó gazdasági és társadalmi ismeretkörök. (Nyilván sokat lehetne arról értekezni, vajon a névváltozás okozott-e változást a képzés piaci megítélésében, illetve hogy a térgazdaság működéséhez kapcsolódó gazdasági, társadalmi ismeretkörök mennyire illeszkednek egy agrármérnöki képzés rendszerébe, de az jól érzékelhető, hogy az idegen nyelvű és a külhoni képzésekben a vidékfejlesztési diszciplínák iránt növekvő érdeklődés bontakozott ki.) Mindezen bővülés mellett - sajnálatos módon - a hazai felsőfokú vidékfejlesztési oktatásban egyre kevesebb a hallgatók száma. Az elmúlt években 30-40 százalékkal csökkent a felvételizők száma, részben azért, mert átalakult a multinacionális cégek munkaerőigénye. A vidékfejlesztés, nemzetgazdasági szerepe ellenére, nem vonzó a középiskolákban tanuló „Z” generáció számára, miközben a munkaerőpiacnak, a vidéknek is szüksége lenne olyan szakemberekre, akik a vidékgazdaság működését, fejlesztését értik és egyben a vidéki emberek gazdasági, társadalmi jólétének fejlesztését tekintik elsődleges céljuknak.

Mindezek alapján felmerül a kérdés: milyen legyen az a képzés, amely képes felkészíteni a felsőoktatási intézmények hallgatóit a vázolt vidékfejlesztési, vidékgazdasági feladatokra? Milyen irányban kellene változtatni a vidékfejlesztési képzéseken ahhoz, hogy előtérbe kerüljön az a tény, miszerint a vidéki térségekben nem csak agrárszakemberek dolgoznak? Az „okos” vidéki térségek kialakításában az ipar, a szolgáltatások felsőfokú végzettségü szakembereinek is fontos szerepük van. A kérdést ezért általánosabban kell megfogalmaznunk: milyen felsőoktatási képzési rendszerrel leszünk képesek megfelelni a jövő társadalmi, gazdasági, innovációs és térbeli kihívásainak a vidékgazdaságban? Bármilyen választ is adunk, oktatás és tanulás nélkül esélyünk sincs a periferikus helyzet, a vidék leszakadásának mérséklésére. Fontosnak érzem a téma rendszerszemléletű elemzését annak érdekében, hogy a regionális tudományok egyre szélesebb körben bekerülhessenek és elfogadottabbak legyenek a hazai és nemzetközi tudományos világ meghatározó színterein.

\section{Irodalom}

Buday-Sántha A. (2001): Agrárpolitika-vidékpolitika. Dialóg Campus Kiadó, Budapest-Pécs Enyedi Gy. (1975): A magyar falu átalakulása. Földrajzi Értesítö, 2., 109-124.

Káposzta J., Nagy H. (2013): Vidékfejlesztés és a környezetipar kapcsolatrendszere az endogén fejlödésben. Journal of Central European Green Innovation, 1., 71-82.

Káposzta J., Tóth T. (2013): Regionális és vidékfejlesztési ismeretek. Debreceni Tudományegyetem, Digitális Tankönyvtár, Debrecen

Ritter K. (2008): Agrárfoglalkoztatási válság és a területi egyenlőtlenségek. PhD disszertáció, Szent István Egyetem, GSZDI, Gödöllő 